RESEARCH PAPER

\title{
Optimization of Nutritional Health Drink Developed from Guava, Jamun and Aloe vera
}

\author{
Sakshi Sharma and Rakesh Sharma* \\ Department of Food Science and Technology, Dr YS Parmar University of Horticulture and Forestry, Solan, HP. India \\ *Corresponding author: drrakes@gmail.com
}

Paper No.: 236

Received: 12-07-2019

Revised: 14-10-2019

Accepted: 28-11-2019

\begin{abstract}
Guava, jamun and Aloe vera are valued for their nutritive and medicinal properties, but their utilization as drink is limited due to certain consumer repelling factors like poor appearance and grittiness of guava juice, high astringent taste of jamun juice and bitter taste of Aloe vera juice. Therefore, present study was designed to optimize the blending of guava pulp with jamun and Aloe vera juice for developing nutritious health drink. Different formulations, where jamun juice concentration varied from 10-50 per cent with two levels of fruit part (10 and 15\%) and two levels of TSS (10 and $\left.15^{\circ} \mathrm{B}\right)$ were tried for optimizing guava-jamun blended drink. Further, Aloe vera juice from 1 to 9.0 per cent was added to enhance the nutritive and functional value without compromising overall acceptability of the developed beverage. Out of different formulations, the drink prepared by blending guava-jamun in the ratio of 60:40 with 15 per cent fruit part (blended) and $15^{\circ} \mathrm{B}$ TSS was found the best on the basis of nutritional and sensory characteristics. Herbal fortification with Aloe vera juice @ 5 per cent was optimized for improving nutritional and medicinal properties of the developed beverage. Results revealed that the Aloe vera fortified guava-jamun health drink contained higher values of ascorbic acid $(33.91 \mathrm{mg} / 100 \mathrm{~g})$, total phenolics $(36.12 \mathrm{mg} / 100 \mathrm{~g})$ and antioxidant potential (13.40\% free radical scavenging activity) compared to control the sample (100\% guava drink).
\end{abstract}

Keywords: Guava, jamun, Aloe vera, health drink, functional beverages

Fruit, vegetable and medicinal herbs act as protective foods and their consumption has increased because of their disease combating properties (Adefegha 2018; Dukhi and Taylor, 2018; Sharma et al. 2019). Recently, increased health awareness around the globe has increased the demand for functional foods especially the beverages which provide necessary nutrients, prevent nutrition-related diseases and improve physical and mental well-being of the consumers (Raj et al. 2017; Kaur and Sigh 2017; Sharma et al. 2018; Palamthodi et al. 2019). Among many fruits, guava (Psidium guajava L.) and jamun (Syzygium cumini L.) are reported to contain several bioactive compounds and have been widely used to treat diabetes by the traditional practitioners over many centuries (Kapoor and Ranote, 2015; Joshi et al. 2019). Guava is often included among super fruits, being rich in dietary fibres, vitamin $\mathrm{A}$ and $\mathrm{C}$, folic acid and dietary minerals (Singh and Tiwari, 2019). It is a hypoglycaemic fruit and generally, provides less energy (38-57 Kcal/100g) as compared to other fruits like mango, banana etc. and hence suitable for diabetics and for those involved in weight management (Rai et al. 2007; Joseph and Priya, 2011). Similarly, jamun (Indian blackberry or black plum) is reported to contain vitamins, amino acids, minerals

How to cite this article: Sharma, S. and Sharma, R. (2019). Optimization of Nutritional Health Drink Developed from Guava, Jamun and Aloe vera. Int. J. Food Ferment. Technol., 9(2): 125-131.

Source of Support: None; Conflict of Interest: None क क 
and other phyto-chemicals (Kannan and Puraikalan, 2016). It has antioxidant, anti-inflammatory, antimicrobial, antibacterial, antifungal, free radical scavenging, gastro-protective and anti-diabetic properties (Sagrawat et al. 2006; Joshi et al. 2019). In spite of great nutritional significance of these fruits; cloudy appearance, grittiness and poor taste of guava juice/pulp and high astringency, blunt taste of jamun juice are some of the consumer repelling factors and major problems to the juice industry (Sharma et al. 2014; Joshi et al. 2012; Raj et al. 2017). Hence, finding right blend of juices/ pulps to maximize consumer appeal for health and sensory attributes is the alternative for utilization of such fruits (Bhardwaj and Pandey, 2011; Singh and Gaikwad 2012; Heena et al. 2017). Furthermore, fortification of beverages with herbal extracts has been reported to improve nutritional and health properties besides enhancing storage/microbial stability (Jairajpuri and Qadri, 2015; Sharma et al. 2018). Aloe vera (Aloe verabarbadensis L.) also known as miracle plant, possess a wide range of medicinal and therapeutic properties such as reducing blood sugar, easing intestinal problems, ulcers etc. (Akinnyele and Odiyi, 2007; Sharma et al. 2015). Keeping the above facts in view, the present study was conducted to optimize blending of guava, jamun and Aloe vera for developing a nutritious health drink.

\section{MATERIALS AND METHODS}

\section{Materials}

Fresh guava and jamun fruits were procured from the local fruit and vegetable market, Solan (HP) and brought immediately to the fruit processing unit of Department of Food Science and Technology for further studies. Whereas, Aloe vera leaves were procured from the the Herbal Garden, Department of Forest Products, Dr Yashwant Singh Parmar University of Horticulture and Forestry, Nauni, Solan (HP).

\section{Extraction and preservation of pulp/juice}

Guava fruits were sorted, washed, cut and heated along with water $(1: 1)$ in a pressure cooker for 15 minutes prior to passing through the pulper (BSB, New Delhi) for extraction of pulp. Similarly, jamun pulp was prepared by hot break pulping method (Bons and Dhawan, 2013). However, Aloe vera juice was extracted as per the method given by Sharma et al. (2015). The pulp and juice so extracted were heat preserved and stored under refrigerated temperature till used for product development.

\section{Guava-jamun and Aloe vera fortified guava-jamun drink}

Different combinations of guava and jamun pulp with varying levels of fruit part and total soluble solids (TSS) were tried for optimization of a suitable combination for the preparation of palatable guavajamun blended drink. The drinks were prepared as per standard methods and specifications of FSSA2006. The acidity (as \% citric acid) was kept constant (i.e. $0.30 \%$ ) in all the treatments. The treatment $\mathrm{T}_{1}$ was kept control which was having 100 per cent of guava pulp (10\% fruit part; $10{ }^{\circ} \mathrm{B}$ TSS). The rest of the treatments $\left(T_{2}\right.$ to $\left.T_{21}\right)$ were prepared by blending different ratio of jamun pulp in guava pulp $(10,20,30$, 40 and 50) with two levels of fruit part (10 and 15\%) and two levels of TSS (10 and $\left.15^{\circ} \mathrm{B}\right)$. Further, five levels of Aloe vera juice fortification i.e. 1, 3, 5, 7 and 9 per cent were tried for optimization of a suitable level for the development of Aloe vera fortified guavajamun health drink.

Physico-chemical, nutritional and sensory quality analysis

All the beverages were evaluated for their physicochemical characteristics viz. TSS, titratable acidity, total sugars, reducing sugars, ascorbic acid, total phenols and total anthocyanins as per the standard analytical methods (Ranganna, 2009). Antioxidant activity (Free radical scavenging activity) of juice and beverage was measured as per the method of BrandWilliams et al. (1995) by using DPPH (2, 2-diphenyl1-picrylhydrazyl) as a source of free radical. Sensory evaluation of the product was conducted by a panel of ten judges using 9- point hedonic scale system for different parameters viz. appearance, body, flavour and overall acceptability (Amerine et al. 1965). 


\section{STATISTICAL ANALYSIS}

All the analytical parameters were recorded in triplicates and the mean values of each parameter were described with standard error (SE). The data pertaining to quantitative estimation of physicochemical characteristics were assessed by factorial $\mathrm{CRD}$, whereas the data regarding sensory evaluation of products were analysed by RBD as described by Cochran and Cox (1967).

\section{RESULTS AND DISCUSSION}

Physico-chemical characteristics of fresh guava, jamun and Aloe vera juice/pulp

Data pertaining to the physico-chemical characteristics of fresh guava, jamun and Aloe vera juice: Pulp revealed that guava pulp contained 5.02 oB total soluble solids (TSS), 0.38 per cent titratable acidity, $120.19 \mathrm{mg} / 100 \mathrm{~g}$ ascorbic acid, 1.26 per cent reducing sugars, 2.70 per cent total sugars and 3.42 $\mathrm{pH}$ (Table 1). Whereas, the total phenolic contents and antioxidant activity in guava pulp were observed as $180.42 \mathrm{mg} / 100 \mathrm{~g}$ and 72.80 per cent, respectively. Fresh jamun pulp was found to be a rich source of total phenolics $(424.24 \mathrm{mg} / 100 \mathrm{~g})$ besides containing 9.97º $\mathrm{B}$ total soluble solids, 0.75 per cent titratable acidity, 2.79 per cent reducing sugars and 6.52 per cent total sugars, respectively. While, ascorbic acid, antioxidant potential and total anthocyanins were estimated as $27.28 \mathrm{mg} / 100 \mathrm{~g}$, 75.56 per cent and 112.50 $\mathrm{mg} / 100 \mathrm{~g}$, respectively. Data presented in Table 1 further revealed that Aloe vera juice contained $2.20^{\circ} \mathrm{B}$ total soluble solids, 0.35 per cent titratable acidity and $102 \mathrm{mg} / 100 \mathrm{~g}$ ascorbic acid. Similar findings of these parameters were also reported by Jain and Asati (2009), Abed et al. (2012) and Bons and Dhawan (2013) for guava; Chaudhary and Mukhopadhyay (2012) and Kapoor and Ranote (2015) for jamun and Sharma et al. (2015) for Aloe vera.

\section{Optimization of guava-jamun and Aloe vera fortified guava-jamun health drink}

The effects of blending of guava pulp with different proportions of jamun pulp on sensory attributes of the developed drink are presented in Table 2. It was observed that with the increase in the proportions of jamun pulp up to 40 per cent the score for colour and body increased, beyond which it decreased due to cloudy appearance of the drink. The highest colour score (7.80) and body (7.70) was obtained by the drink having 60 per cent guava pulp and 40 per cent jamun pulp with 15 per cent fruit part and $15^{\circ} \mathrm{B}$ TSS. It is evident from the data that flavour score for different treatments varied from 6.90 to 7.75 with maximum score obtained by the treatment $T_{17}\left(G_{60}+J_{40}\right)$. Similar results were also recorded for overall acceptability (Table 2). Blending of guava pulp with appropriate proportion of jamun pulp might have enhanced the

Table 1: Physico-chemical characteristics of guava, jamun and Aloe vera juice/pulp

\begin{tabular}{llll}
\hline \multirow{2}{*}{ Parameters* } & \multicolumn{3}{c}{ Mean \pm SE } \\
\cline { 2 - 4 } & Guava pulp & Jamun pulp & Aloe vera juice \\
\hline TSS ( $\left.{ }^{\circ} \mathrm{B}\right)$ & $5.02 \pm 0.10$ & $9.97 \pm 0.15$ & $2.20 \pm 0.10$ \\
Tiratable acidity (\%) & $0.38 \pm 0.02$ & $0.75 \pm 0.02$ & $0.35 \pm 0.02$ \\
Ascorbic acid (mg/100g) & $120.19 \pm 2.17$ & $27.28 \pm 1.70$ & $102.00 \pm 1.33$ \\
Reducing sugars (\%) & $1.26 \pm 0.04$ & $2.79 \pm 0.26$ & $0.42 \pm 0.03$ \\
Total sugars (\%) & $2.70 \pm 0.50$ & $6.52 \pm 0.36$ & $1.64 \pm 0.09$ \\
Total phenolics (mg/100g) & $180.42 \pm 1.86$ & $424.24 \pm 1.84$ & $198.38 \pm 1.45$ \\
Antioxidant potential (\% free radical scavenging & & & $84.68 \pm 0.92$ \\
activity) & $72.80 \pm 1.25$ & $75.56 \pm 1.92$ & $\mathrm{ND}$ \\
Total anthocyanins (mg/100g) & $\mathrm{ND}$ & $112.50 \pm 0.13$ & \\
\hline
\end{tabular}

${ }^{*}$ Each value is average of three determinations; $S E=$ Standard error; $N D=$ Not detected. 
Table 2: Sensory evaluation of different guava-jamun blended drinks

\begin{tabular}{lllllll}
\hline & Detail of treatments & & \multicolumn{3}{c}{ Sensory Score* $^{*}$} \\
\hline Treatment & Fruit part (\% blended pulp) & TSS (ํ)Brix) & Colour & Body & Flavour & Overall acceptability \\
\hline $\mathrm{T}_{1}\left(\mathrm{G}_{100}\right)$ Control & 10 & 10 & 7.00 & 7.00 & 6.90 & 7.00 \\
$\mathrm{~T}_{2}\left(\mathrm{G}_{90}: \mathrm{J}_{10}\right)$ & 10 & 10 & 7.15 & 7.11 & 6.95 & 7.10 \\
$\mathrm{~T}_{3}\left(\mathrm{G}_{90}: \mathrm{J}_{10}\right)$ & 10 & 15 & 7.20 & 7.18 & 7.00 & 7.15 \\
$\mathrm{~T}_{4}\left(\mathrm{G}_{90}: \mathrm{J}_{10}\right)$ & 15 & 10 & 7.22 & 7.21 & 7.15 & 7.20 \\
$\mathrm{~T}_{5}\left(\mathrm{G}_{90}: \mathrm{J}_{10}\right)$ & 15 & 15 & 7.22 & 7.22 & 7.15 & 7.25 \\
$\mathrm{~T}_{6}\left(\mathrm{G}_{80}: \mathrm{J}_{20}\right)$ & 10 & 10 & 7.28 & 7.28 & 7.18 & 7.28 \\
$\mathrm{~T}_{7}\left(\mathrm{G}_{80}: \mathrm{J}_{20}\right)$ & 10 & 15 & 7.32 & 7.32 & 7.25 & 7.35 \\
$\mathrm{~T}_{8}\left(\mathrm{G}_{80}: \mathrm{J}_{20}\right)$ & 15 & 10 & 7.38 & 7.35 & 7.30 & 7.42 \\
$\mathrm{~T}_{9}\left(\mathrm{G}_{80}: \mathrm{J}_{20}\right)$ & 15 & 15 & 7.40 & 7.35 & 7.30 & 7.48 \\
$\mathrm{~T}_{10}\left(\mathrm{G}_{70}: \mathrm{J}_{30}\right)$ & 10 & 10 & 7.50 & 7.38 & 7.35 & 7.55 \\
$\mathrm{~T}_{11}\left(\mathrm{G}_{70}: \mathrm{J}_{30}\right)$ & 10 & 15 & 7.55 & 7.40 & 7.40 & 7.60 \\
$\mathrm{~T}_{12}\left(\mathrm{G}_{70}: \mathrm{J}_{30}\right)$ & 15 & 10 & 7.60 & 7.45 & 7.50 & 7.66 \\
$\mathrm{~T}_{13}\left(\mathrm{G}_{70}: \mathrm{J}_{30}\right)$ & 15 & 15 & 7.63 & 7.48 & 7.55 & 7.66 \\
$\mathrm{~T}_{14}\left(\mathrm{G}_{60}: \mathrm{J}_{40}\right)$ & 10 & 10 & 7.60 & 7.50 & 7.56 & 7.70 \\
$\mathrm{~T}_{15}\left(\mathrm{G}_{60}: \mathrm{J}_{40}\right)$ & 10 & 15 & 7.65 & 7.62 & 7.60 & 7.80 \\
$\mathrm{~T}_{16}\left(\mathrm{G}_{60}: \mathrm{J}_{40}\right)$ & 15 & 10 & 7.70 & 7.67 & 7.70 & 7.72 \\
$\mathrm{~T}_{17}\left(\mathrm{G}_{60}: \mathrm{J}_{40}\right)$ & 15 & 15 & 7.80 & 7.70 & 7.75 & 7.85 \\
$\mathrm{~T}_{18}\left(\mathrm{G}_{50}: \mathrm{J}_{50}\right)$ & 10 & 10 & 7.78 & 7.68 & 7.72 & 7.71 \\
$\mathrm{~T}_{19}\left(\mathrm{G}_{50}: \mathrm{J}_{50}\right)$ & 10 & 15 & 7.79 & 7.65 & 7.60 & 7.69 \\
$\mathrm{~T}_{20}\left(\mathrm{G}_{50}: \mathrm{J}_{50}\right)$ & 15 & 10 & 7.78 & 7.55 & 7.55 & 7.67 \\
$\mathrm{~T}_{21}\left(\mathrm{G}_{50}: \mathrm{J}_{50}\right)$ & 15 & 15 & 7.79 & 7.55 & 7.55 & 7.70 \\
$\mathrm{CD}_{005}$ & - & - & 0.15 & 0.13 & 0.18 & 0.10 \\
\hline
\end{tabular}

*Sensory score recorded on 9-point hedonic scale; 9=like extremely, 1=dislike extremely; $G=$ guava; J= jamun.

flavour profile of the product and hence rated highest by the panellist on the basis of overall acceptability of the beverage. Tiwari and Deen (2015; Sharma et al. (2016) and Sharma et al (2018) had observed similar findings in Bael-Aloe vera RTS, Jamun- mango squash and Aloe vera-aonla squash, respectively.

Data pertaining to the effect of Aloe vera fortification on sensory quality of guava-jamun blended drink is presented in Fig 1. It was found that with the increase in proportion of Aloe vera juice up to 9 per cent, the colour score of prepared drink decreased, however all the treatments obtained colour score between 7.72 to 7.80 , which were well with the acceptable range (more than 7.00 ). Whereas, with the addition of Aloe vera juice up to a level of 5 per cent, the score for flavour increased, which has resulted in higher overall acceptability score of the products. While, the addition of Aloe vera at higher levels $(>5 \%)$ resulted in decline of overall acceptability score of the products
(Fig. 1). Our results are in conformity with earlier studies conducted by Tiwari and Deen (2015) and Pandey et al. (2019).

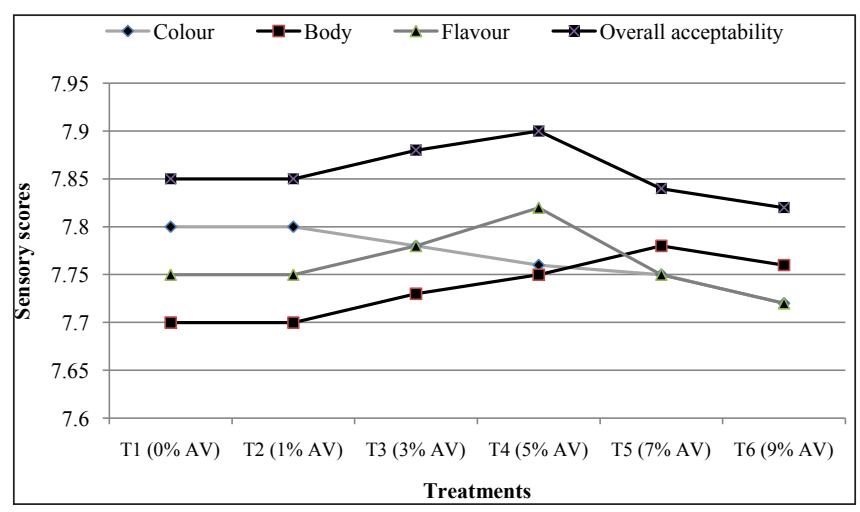

Fig. 1: Sensory evaluation of Aloe vera fortified guavajamun blended health drink

Other researchers have also reported that fortification of beverages with herbal extracts improved physicochemical, sensory, nutritional and microbial quality 
of the prepared beverage (Boghani et al. 2012; Jairajpuri and Qadri 2015; Sharma and Tandon 2015). Hence, on the basis of sensory evaluation, Aloe vera fortification up-to 5 per cent was optimized.

Physico-chemical, nutritional and sensory characteristics of the developed beverage

The data presented in Table 3 revealed that the addition of jamun pulp had improved the nutritional quality of drink as evident from its higher total phenolic content $(32.75 \mathrm{mg} / 100 \mathrm{~g})$, ascorbic acid content $(33.91 \mathrm{mg} / 100 \mathrm{~g})$ and antioxidant potential (11.30 \% free radical scavenging activity) compared to standard drink $(18.09 \mathrm{mg} / 100 \mathrm{~g}, 16.16 \mathrm{mg} / 100 \mathrm{~g}$ and $8.77 \%$ free radical scavenging activity), respectively (Table 3). Palamthodi et al. (2019) studied physicochemical and functional properties of ash gourd/ bottle gourd beverages blended with jamun and showed significant increase in bio-accessibility of polyphenols, flavonoids, and anthocyanins. Further, Aloe vera fortified guava-jamun blended drink so developed has also showed strong antimicrobial activity against human pathogen E. coli (Table 3). Similar results have been reported by Kapoor and Ranote (2015) and Sharma et al. (2018).

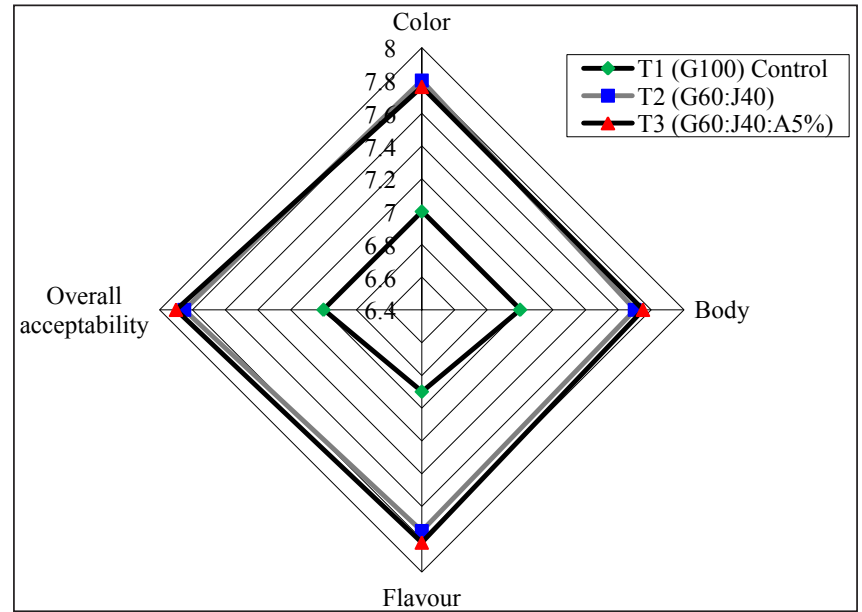

Fig. 2: Sensory attributes of guava drink, guava-jamun drink and Aloe vera fortified guava-jamun health drink

Further, blending has also exerted positive effect on sensory attributes of the beverages as the blended drink had recorded higher score for flavour (7.82) and overall acceptability (7.90) compared to guava drink (Fig. 2). Earlier, many workers have reported blending of two or more fruit pulp/juices in various proportions for making more palatable and nutritious beverages (Boghani et al. 2012; Mohamed et al. 2014; Sharma et al. 2016; Raj et al. 2017).

Table 3: Physico-chemical attributes of guava drink, best rated guava-jamun drink and Aloe vera fortified guava-jamun drink

\begin{tabular}{llll}
\hline & \multicolumn{3}{c}{ Mean $\pm \mathrm{SE}$} \\
\cline { 2 - 4 } Parameters* & Guava drink $\left(\mathrm{G}_{\mathbf{1 0 0}}\right)$ & $\begin{array}{l}\text { Guava-jamun drink } \\
\left(\mathrm{G}_{60}: \mathrm{J}_{40}\right)\end{array}$ & $\begin{array}{l}\text { Guava-jamun- Aloe vera drink } \\
\left(\mathrm{G}_{60}: \mathrm{J}_{40}: \mathrm{A}_{5 \%}\right)\end{array}$ \\
\hline TSS ( $\left.{ }^{\circ} \mathrm{B}\right)$ & $10.00 \pm 0.20$ & $15.00 \pm 0.20$ & $15.00 \pm 0.20$ \\
Tiratable acidity (\%) & $0.30 \pm 0.01$ & $0.30 \pm 0.01$ & $0.30 \pm 0.02$ \\
Total sugars (\%) & $9.41 \pm 0.16$ & $14.06 \pm 0.03$ & $14.38 \pm 0.13$ \\
Ascorbic acid (mg/100g) & $16.16 \pm 0.15$ & $18.38 \pm 0.08$ & $33.91 \pm 0.07$ \\
Total phenolics (mg/100g) & $18.09 \pm 0.10$ & $32.75 \pm 0.06$ & $36.12 \pm 0.02$ \\
$\begin{array}{l}\text { Antioxidant potential }(\% \text { free } \\
\text { radical scavenging activity) }\end{array}$ & $8.77 \pm 0.06$ & $11.30 \pm 0.02$ & $13.40 \pm 0.02$ \\
Total anthocyanins (mg/100g) & $1.05 \pm 0.03$ & $10.09 \pm 0.03$ & $10.02 \pm 0.02$ \\
$\begin{array}{l}\text { Antimicrobial activity (mm zone } \\
\text { of inhibition) }\end{array}$ & $6.5 \pm 0.03$ & $9.2 \pm 0.04$ & $14.5 \pm 0.04$ \\
\hline
\end{tabular}

$S E=$ Standard error; $G=$ guava; $J=$ jamun; $A=$ Aloe vera $;=T S S$. 


\section{CONCLUSIONS}

Blending guava pulp with jamun pulp and Aloe vera juice have resulted in improvement of sensory, nutritional and functional properties of the drink. The blended drink prepared by using 60 per cent guava pulp and 40 per cent jamun pulp with 15 per cent fruit part and $15^{\circ} \mathrm{B}$ TSS was optimized for better sensory characteristics. Addition of Aloe vera juice up to 5 per cent was found acceptable. Aloe vera fortified guava- jamun drink contained higher amounts of ascorbic acid, total phenolic content, antioxidant activity and also showed strong antimicrobial activity against human pathogen $E$. coli compared to standard guava drink. So, it was concluded that, guava and jamun can successfully be utilized for the development of functional/health beverages by way of blending and/or fortification with Aloe vera. Hence, their availability in the market will definitely benefit the health conscious people.

\section{REFERENCES}

Abed, S.M., Elbandy, M.A., Gad, S.S. and Abdel-Fadeel, M.G. 2012. Production of guava nectar supplemented with Aloe vera gel. Agriculture Research Journal, 12(2): 51-59.

Adefegha, A.S. 2018. Functional Foods and Nutraceuticals as Dietary Intervention in Chronic Diseases; Novel Perspectives for Health Promotion and Disease Prevention. Journal of Dietary Supplements, 15(6): 977-1009.

Akinnyele, B.O. and Odiyi, A.C. 2007. Comparative study of vegetative morphology and existing taxonomic status of Aloe vera L. Journal of Plant Sciences, 2(5): 558-563.

Amerine, M.A., Pangborn, R.M. and Roessler, E.B. 1965. Principles of sensory evaluation of food. Academic press, London.

Bhardwaj, R.L. and Pandey, S. 2011. Juice blends-A way of utilisation of under-utilized fruits, vegetables and spices: A review. Critical Reviews in Food Science and Nutrition, 51(6): 563-570.

Boghani, A.H., Raheem, A. and Hashmi, S.I. 2012. Development and storage studies of blended papaya- Aloe vera readyto-serve (RTS) beverage. Journal of Food Processing and Technology, 3(10): 185-189.

Bons, K.H. and Dhawan, S.S. 2013. Studies on preservation of pulp.Indian Journal of Horticulture, 70(3): 452-454.

Brand-Williams, W., Cuvelier, M.E. and Berset, C. 1995. Use of free radical method to evaluate antioxidant activity. Lebensmittel-Wissenschaft and Technology, 28: 25-30.
Chaudhary, B. and Mukhopadhyay. 2012. Syzgium cumini L. Skeels: A potential source of nutraceuticals. International Journal of Pharmacy and Bio Science, 2(1): 46-53.

Cochran, W.G. and Cox, C.N. 1967. Experimental designs. John wiley and sons, inc, New Delhi.

Dukhi, N. and Taylor. 2018. A focus on four popular "Functional Foods" as part of a strategy to combat metabolic disease through the increased consumption of fruits and vegetables. Current Research in Nutrition and Food Science, 6(2): 294-306.

Heena, Kumar, V., Kaur, J., Gat, Y., Chandel, A., Suri, S. and Panghal, A. 2017. Optimization of the different variables for the development of a cucumber-based blended herbal beverage. Beverages, 3: 50.

Jain, P.K. and Asati, A. 2009. Evaluation guava cultivars for pulp preparation. Journal of Food Science and Technology, 41(6): 684-686.

Jairajpuri, S.D. and Qadri, S. 2015. Fortification of orange juice with Withania somnifera and Solanum nigrum extract- a potential fruit beverage and its quality evaluation. Pakistan Journal of Food Science, 25(2): 58-65.

Joseph, B. and Priya, R. 2011. Review on nutritional, medicinal and pharmacological properties of guava (Psidium guajava L.). International Journal of Pharma and Bio Sciences, 2(1): 5369.

Joshi, M., Paudel, M. and Upreti. 2019. Therapeutic influence of Jamun (Syzygium cumini): A review. Journal of Pharmacognosy and Phytochemistry, 8(3): 1056-1059.

Joshi, V.K., Sharma, R., Girdher, A. and Abrol, G.S. 2012. Effect of dilution and maturation on physico-chemical and sensory quality of jamun (Black plum) wine. Indian J. Natural Products and Resources, 3(2): 222-227.

Kannan, A. and Puraikalan, Y.D. 2016. Development and effects of Jamun seed powder incorporated cookies. International Journal of Science and Research, 5(4): 1934-1935.

Kapoor and Ranote, P.S. 2015. Antioxidant potentials and quality of blended pear-jamun (Syzygium cumini L.) juice. International Research Journal of Biological Sciences, 4(4): 3037.

Kaur, N. and Singh, D.P. 2017. Deciphering the consumer behavior facets of functional foods: A literature review. Appetite, 112: 167-187.

Mohamed, S.A., Hussein, A.M.S. and Ibraheim, G.E. 2014. Physico-chemical, sensorial, antioxidant and volatiles of juice from prickly pear with guava or mandarin. International Journal of Food and Nutritional Sciences, 3(6): 44-53.

Palamthodi, S., Kadam, D. and Lele, S.S. 2019. Physicochemical and functional properties of ash gourd/bottle gourd beverages blended with jamun. J. Food Sci. Technol., 56(1): 473-482. 
Rai, P.K., Singh, S.K., Kesari, A.N. and Watal, G. 2007. Glycaemic evaluation of Psidium guajava in rats. Indian Journal of Medicinal Resources, 126: 224-227.

Raj, D., Jaysukh, M.Y. and Suthar, H. 2017. Value addition of Aloe vera in health drinks and its storage stability. Journal of Tree Sciences, 36(2): 53-66.

Ranganna, S. 2009. Handbook of analysis and quality control for fruit and vegetable products. Tata McGraw Hill, New Delhi, pp. 1112.

Sagrawat, H., Mann, A. and Kharya, M. 2006.Phrmacological potential of Eugenia jambola: A Review. Pharmacogenesis Magazice, 2: 96-104.

Sharma, D.S., Kaul, R.K., Bhat, A. and Singh, J. 2016. Quality evaluation and storage stability of jamun-mango squash. Indian Journal of Horticulture, 73(1): 153-156.

Sharma, N.K., Beniwal, V., Kumar, N., Kumar, S., Pathera, A.K. and Ray, A. 2014. Production of tannase under solidstate fermentation and its application in detannification of guava juice. Preparative Biochemistry and Biotechnology, 44: 281-290.

Sharma, R. and Tandon, D. 2015. Development and evaluation of antioxidant rich low calorie functional bitter gourd (Momordica charantia L.) spiced squash. International Journal of Farm Science, 5(1): 68-77.
Sharma, R., Kumar, S., Kumar, V. and Thakur, A. 2019. Comprehensive review on nutraceutical significance of phytochemicals as functional food ingredients for human health management. Journal of Pharmacognosy and Phytochemistry, 8(5): 385-395.

Sharma, R., Tandon, D., Joshi, V.K. and Attri, S. 2015. Development and evaluation of different beverages from Aloe vera (L.) burm.f. for their nutritional, functional and sensory qualities. Indian Journal of Natural Products and Resources, 6(4): 278-282.

Sharma, R., Sharma, R. and Thakur, A. 2018. Development and evaluation of Vitamin C enriched low calorie Aloe veraaonla blended functional squash using stevioside. Indian Journal of Horticulture, 75: 289-294.

Singh, J.L. and Tiwari, B.R. 2019. Development of Nutritious Fruit Leather by Blending Guava and Papaya. International Journal of Current Microbiology and Applied Sciences, 8(7): 813-820

Singh, S. and Gaikwad, K.K. 2012. Studies on the development and storage stability of bitter gourd-lemon functional RTS beverage. International Journal of Processing and Post Harvest Technology, 3(2): 306-310.

Tiwari, D.K. and Deen, B. 2015. Preparation and storage of blended ready to serve beverage from bael and Aloe vera. The bioscan., 10: 113-116. 
